\title{
How much carbon input is required to preserve or increase projected soil organic carbon stocks in German croplands under climate change?
}

\author{
Catharina Riggers (D) - Christopher Poeplau • Axel Don • \\ Cathleen Frühauf • René Dechow
}

Received: 13 July 2020 /Revised: 3 December 2020 / Accepted: 9 December 2020 / Published online: 13 January 2021

(C) The Author(s) 2021

\begin{abstract}
Aims Increasing soil organic carbon (SOC) stocks is discussed as negative emission technology with the potential to remove relevant amounts of carbon from the atmosphere. At the same time, climate changedriven losses of SOC to the atmosphere might impede such goals.

Methods In this study, we used an ensemble of different SOC models and climate projections to project SOC stocks in German croplands up to 2099 under different climate change scenarios. We then estimated the required increase in organic carbon (OC) input to preserve or increase SOC stocks.

Results Projected SOC stocks of German croplands are estimated to decline under current $\mathrm{OC}$ input levels and management, both with and without climate change. Depending on the climate scenario, we estimated that the OC input to the soil in 2099 needs to be between $51 \%\left(+1.3 \mathrm{Mg} \mathrm{ha}^{-1}\right)$ and $93 \%\left(+2.3 \mathrm{Mg} \mathrm{ha}^{-1}\right)$ higher than today to preserve current SOC stock levels. A SOC stock increase of $34.4 \%\left(4 \% \circ \mathrm{a}^{-1}\right)$ would even require an OC input increase of between $221 \%\left(+5.5 \mathrm{Mg} \mathrm{ha}^{-1}\right)$ and $283 \%\left(+7.1 \mathrm{Mg} \mathrm{ha}^{-1}\right)$.

Conclusions Our study highlights that under climate change increasing SOC stocks is considerable challenging since projected SOC losses have to be compensated
\end{abstract}

Responsible Editor: Simon Jeffery.

C. Riggers $(\bowtie) \cdot$ C. Poeplau $\cdot$ A. Don $\cdot$ R. Dechow

Thünen Institute of Climate-Smart Agriculture, Bundesallee 65,

38116 Braunschweig, Germany

e-mail: catharina.riggers@thuenen.de first before SOC built up is possible. This would require unrealistically high OC input increases with drastic changes in agricultural management.

Keywords Modeling · Soil organic matter · OC sequestration $\cdot$ Multi-model ensemble $\cdot$ Representative concentration pathways $\cdot 4$ per 1000

\section{Introduction}

Climate change could alter the soil organic carbon (SOC) stocks of arable land (Smith 2012). The dynamic of SOC stocks depends on the balance between organic carbon (OC) input, e.g. as litter, and OC output, e.g. via decomposition (Smith 2012). Climate change causes alterations in temperature, precipitation pattern and carbon dioxide $\left(\mathrm{CO}_{2}\right)$ levels, which affect not only the decomposition of SOC but also the OC input via net primary production (Conant et al. 2011; Gottschalk et al. 2012; Smith 2012). These changes are variable in time and space, and thus whether SOC stocks are likely to increase or decrease will differ from region to region (Gottschalk et al. 2012). Past and recent changes in SOC stocks have been detected at regional to continental

\author{
C. Frühauf \\ Deutscher Wetterdienst, ZAMF, Bundesallee 33, \\ 38116 Braunschweig, Germany
}


scale with repeated soil inventories, while future changes in SOC stocks have been estimated using models (Jandl et al. 2014).

Repeated national soil inventories show for example decreasing SOC stocks for England and Wales (Bellamy et al. 2005) and Finland (Heikkinen et al. 2013), and increasing SOC stocks in the Netherlands (Reijneveld et al. 2009) and Sweden (Poeplau et al. 2015a). Miscellaneous results have been detected for Germany: a SOC time series of 171 permanent soil monitoring sites on managed croplands in Germany was analyzed and no significant changes in SOC stocks were detected (Umweltbundesamt 2016). The same result was observed by Höper and Meesenburg (2012) in an analysis of cropland monitoring sites in the federal state of Lower Saxony for the period 1997 to 2010. In contrast, Capriel (2013) detected for croplands decreasing SOC stocks for the federal state of Bavaria between 1986 and 2007. However, these results are not representative for Germany as a whole.

Lugato et al. (2014) and Smith et al. (2005) estimated future changes in SOC stocks using the climate scenarios of the Intergovernmental Panel of Climate Change (IPCC) and the SOC models Roth-C (Coleman and Jenkinson 2005) and Century (Parton et al. 1994). They reported increasing SOC stocks for Europe for the end of the 21 st century. Regional differences were identified, with both studies modeling positive SOC changes for Germany when considering future increases in OC input. In Germany, Wiesmeier et al. (2016) estimated significant future SOC losses for the federal state of Bavaria in the 21 st century using Roth-C and the IPCC's climate change scenario A1B. The model also predicted that an OC input increase of $29 \%$ would be needed to compensate for higher rates of decomposition and to keep SOC stocks stable (Wiesmeier et al. 2016).

A decrease in SOC stocks is associated with increasing atmospheric $\mathrm{CO}_{2}$ and a loss of soil fertility, while the opposite is the case when SOC stocks are built up (Lal 2016). Increasing SOC stocks is currently discussed as negative emission technology and promoted as a $\mathrm{CO}_{2}$ sink, for example by the international " 4 per 1000 " initiative, with the potential to remove relevant amounts of $\mathrm{CO}_{2}$ from the atmosphere (Minasny et al. 2017). Various management practices are believed to increase SOC stocks to a new steady state, covering strategies both to increase OC input and also reduce OC mineralization (Minasny et al. 2017). These management practices need to be continued to maintain the benefit of increased SOC stocks. However, the accumulation of SOC stocks is not only affected by global warming and changed management practices, but also restricted if recent $\mathrm{OC}$ inputs are insufficient to even preserve current SOC stocks.

We therefore set up scenarios to investigate the possible effects of a projected future climate on SOC stocks in German croplands. Based on SOC stocks and management data from the first German Agricultural Soil Inventory (Jacobs et al. 2018; Vos et al. 2019) and a multimodel ensemble (Riggers et al. 2019), the SOC stocks of German croplands were evaluated for the period 2014 2099. The study focused on the following questions:

1) How are SOC stocks in German croplands expected to change under different climate change scenarios and current $\mathrm{OC}$ input levels?

2) Which increase in OC input via plant residues is required to preserve or increase SOC stocks under different climate change scenarios?

\section{Materials and methods}

\section{Dataset}

\section{Selection of sites}

The dataset for this study comprised 991 cropland sites across Germany (Fig. 1). These sites were sampled as part of the German Agricultural Soil Inventory from 2011 to 2018. At each site, soil samples were taken and analyzed in the laboratory for soil texture, OC and total nitrogen content and other physicochemical soil properties (Jacobs et al. 2018; Vos et al. 2019). The SOC stocks were calculated with the fine soil mass (grain size $<2 \mathrm{~mm}$ ), the rock fragment fraction (grain size $>2 \mathrm{~mm}$ ) and the fine soil density (fine soil mass per fine soil volume) as suggested by Poeplau et al. (2017). In addition, a questionnaire for farmers documented farm management during the previous ten years, including crop rotations and yield data. In the present modeling study, the focus was solely on topsoils $(0-30 \mathrm{~cm})$.

The dataset was a subset of the complete inventorydataset (1758 cropland sites in May 2018). Owing to the restrictions and limitations of SOC models, some 
cropland sites in the inventory-dataset had to be excluded: all organic soils with a SOC content higher than $8.7 \%$ were excluded because the applied models were developed for mineral soils only. Soils with a mean groundwater level of less than $80 \mathrm{~cm}$ belowground were also omitted because the OC dynamics in hydromorphic soils differ from those described by the SOC models. In the northwestern part of Germany in particular, some soils have a high sand content and an unexpectedly high OC content, which might be due to historical heathland and peatland land use (Sleutel et al. 2011; Vos et al. 2018). The recalcitrant plant material in these soils shows a slower OC mineralization that is not considered in the SOC models (Springob and Kirchmann 2002). Sites that fulfilled all the following criteria were therefore excluded: carbon-to-nitrogen $(\mathrm{C} / \mathrm{N})$ ratio $\geq 12 \mathrm{AND}$ sand content $\geq 70 \%$ AND soil type classified under the German soil system (Sponagel et al. 2005) as podzol or plaggen soil but not as gley (Jacobs et al. 2018). Sites with fewer than five years' management data (e.g. on yields and crop types) were also omitted.

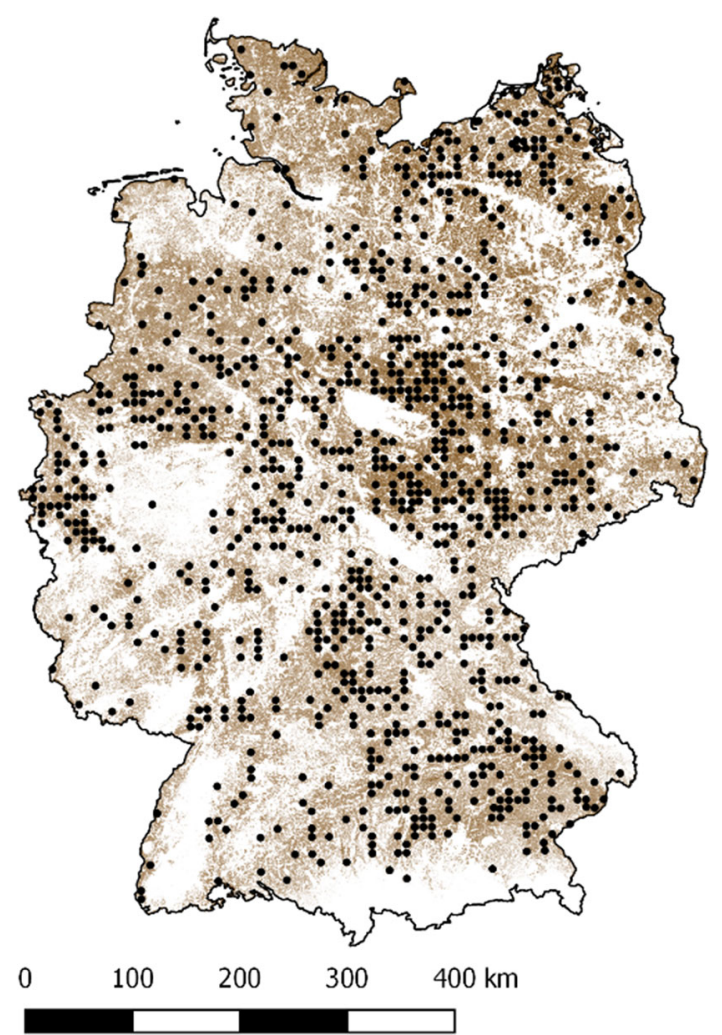

Fig. 1 Location of the 991 sampled cropland sites investigated in this study. Shaded areas represent the cropland area in Germany in 2016

\section{Description of sites}

Germany is located in the temperate zone, with influences of maritime and continental climate. The long-term (1981-2010) mean annual temperature (MAT) of the 991 sites varied between $6.3{ }^{\circ} \mathrm{C}$ and $11.0^{\circ} \mathrm{C}$ and mean annual precipitation (MAP) was between $500 \mathrm{~mm}$ and $1293 \mathrm{~mm}$ (DWD-CDC 2018c, d). The 991 sites comprised a huge variety of soil properties (Fig. 2). The sand content in the topsoil $(0-30 \mathrm{~cm})$ varied between 1 and $95 \%$, silt content between $2 \%$ and $86 \%$, and clay content between $2 \%$ and $66 \%$. Based on the German soil classification system (Sponagel et al. 2005), 24\% of the sites were classified as loam, $27 \%$ as sand, $34 \%$ as silt and $15 \%$ as clay (Fig. S1). Dominant soil classes were Cambisols (30\%), Luvisols (16\%), Stagnosols (16\%), Phaeozems (11\%) and Regosols (10\%), followed by Chernozems, Gleysols, Athrosols, Vetisols and Fluvisols according to the German soil classification system and the proposed equivalent Reference Soil Groups of the WRB system (Sponagel et al. 2005). The $\mathrm{C} / \mathrm{N}$ ratio of the sites ranged from 7 to 26 and the $\mathrm{SOC}$ content from 0.3 to $7.7 \%$. Maximum $\mathrm{C} / \mathrm{N}$ ratios of $>20$ were relicts of strongly degraded and disturbed organic soils mixed with sand. A major strength of this study was that management data of the 991 sites was recorded via a questionnaire for farmers covering the previous ten years before sampling and thus reflecting current agricultural management in Germany. The crop rotations were dominated by six main crop types, harvested in $80 \%$ of the site years (number of sites $\mathrm{x}$ number of years): winter wheat $(31 \%)$, summer wheat $(14 \%)$, winter oilseed rape $(13 \%)$, silage maize $(12 \%)$, winter rye $(5 \%)$ and sugar beet $(5 \%)$. Cover crops were integrated in $12.7 \%$ of the site years. Crop residues were left in the field in $74 \%$ of the site years. Application of organic fertilization took place in $45 \%$ of the site years and ploughing in $68 \%$ of the site years.

\section{Climate scenarios}

We used three climate change scenarios based on the representative concentration pathways (RCPs) used in the IPCC Fifth Assessment Report. RCPs are prescribed pathways of greenhouse gas emissions and atmospheric 
concentrations, air pollutant emissions and land use (IPCC 2013). They are characterized by the strength of radiative forcing at the end of the 21st century (IPCC 2013; Van Vuuren et al. 2011):

- RCP8.5: rising radiative forcing leading to $8.5 \mathrm{~W}$ $\mathrm{m}^{-2}$ (1370 ppm CO $\mathrm{CO}_{2}$-eq; $\mathrm{CO}_{2}$ : $935.9 \mathrm{ppm}$ ) by 2100 ; no effective climate mitigation

- RCP4.5: stabilization without overshoot to $4.5 \mathrm{~W}$ $\mathrm{m}^{-2}$ (650 ppm $\mathrm{CO}_{2}$-eq; $\mathrm{CO}_{2}$ : $538.4 \mathrm{ppm}$ ) at stabilization after 2100; climate mitigation.

- RCP2.6: peak in radiative forcing at $3.0 \mathrm{~W} \mathrm{~m}^{-2}$ (490 ppm $\mathrm{CO}_{2}$-eq) before 2100 and then a decline to $2.6 \mathrm{~W} \mathrm{~m}^{-2}\left(\mathrm{CO}_{2}: 420.9 \mathrm{ppm}\right)$; very strong climate mitigation with the possibility of achieving the $1.5^{\circ} \mathrm{C}$ target.

The predicted development of the climate variables (temperature, precipitation, global radiation) of the climate change scenarios were derived from different climate projections. Each climate projection was the result of a regional climate model, which was driven by a global climate model. The selection of climate projections was based on the core ensemble of the German Weather Service (DWD), which is intended to cover $90 \%$ of the variations in air temperature and $80 \%$ of the variations of all other climate parameters of the DWD reference ensembles v2018 (www.dwd.de/refensemble, accessed 05.02.2019). Each climate change scenario was described by a set of climate projections (multi-model approach, Table S1). The multi-model for climate change scenarios RCP2.6 and RCP8.5 consisted of five climate projections, while there were six climate projections for RCP4.5. A total of
16 different climate projections were thus applied to obtain three robust climate change scenarios for each of the 991 investigated sites. We sampled daily air temperature, precipitation and global radiation for the period from January 2014 to December 2099 for each climate projection. The spatial resolution of the biascorrected climate projections was $5 \mathrm{~km}$ x $5 \mathrm{~km}$ (dimension of one grid cell). Each site was represented by $3 \times 3$ grid cells with the site in the central grid cell. We used the arithmetic mean of these nine grid cells to account for spatial uncertainties.

The daily data were used to calculate the decomposition-modifying factor $r_{e}$ (parameter of the SOC model ICBM) for every site, climate projection and year (Andrén and Kätterer 1997; Poeplau et al. 2015b). In doing so, we used a uniform calendar format of 365.25 days per year filling any gaps arising from different calendar formats (Table S1) with the arithmetic mean of the three previous and three subsequent days. For the rest of the modeling, daily data were aggregated to monthly data for every site and every climate projection using the arithmetic mean (temperature, radiation) or sum (precipitation).

A fourth climate scenario was defined that assumed no further climate change in the future, with the future climate being the same as in recent years. To obtain that, we repeated the climate data recorded in the period of the German Agricultural Soil Inventory for every site up to 2099. The length of the time series repeated for each site varied (depending on the years reported in the site related farmers' questionnaire), thus no pattern was detectable when summarizing the climate for the total study area.

The MAT in all three climate change scenarios increased significantly $(\mathrm{p}<0.05)$ up to 2099 for the study

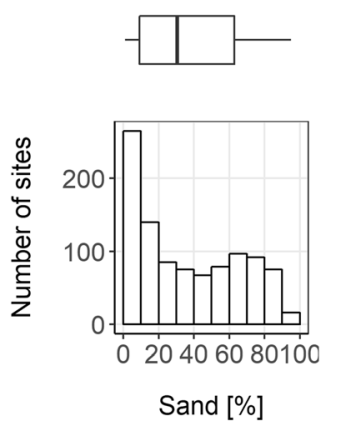

Fig. 2 Boxplots and histograms illustrating the distribution and quantiles of the soil properties of the topsoil $(0-30 \mathrm{~cm})$ from the 991 sites of the study area. The sand, silt and clay contents [\%],
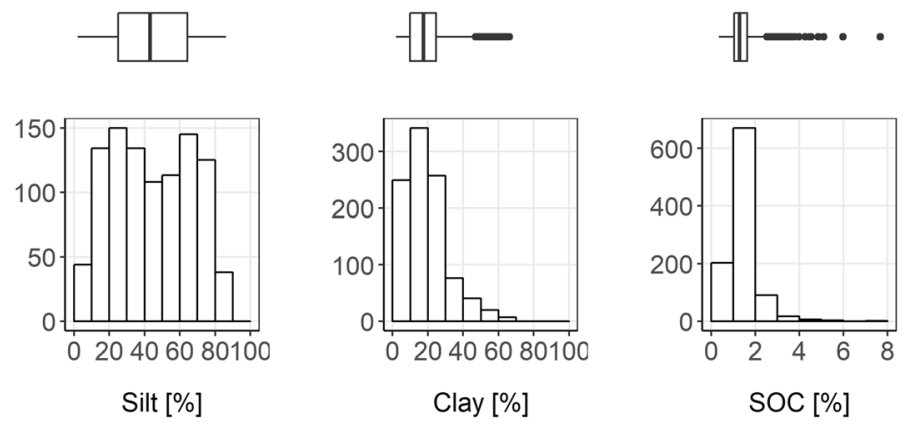

current soil organic carbon (SOC) contents [\%] and carbon-tonitrogen $(\mathrm{C} / \mathrm{N})$ ratios at all sites were measured and determined in the same laboratory 
area (Fig. 3; Table 1). The MAT increase between the reference period 1981-2010 and the period 2070-2099 was greatest for RCP8.5 at $+3.7^{\circ} \mathrm{C}$, compared with + $1.7^{\circ} \mathrm{C}$ for RCP4.5 and $+1.2{ }^{\circ} \mathrm{C}$ for RCP2.6. The MAP only decreased significantly for RCP2.6 and annual global radiation (GR) only decreased significantly for RCP4.5. The climatic water balance (MAP - potential evapotranspiration) decreased significantly for RCP8.5 and RCP2.6. For the scenario assuming no future climate change, no trend was detected for MAT, MAP or GR.

\section{Multi-model ensemble}

We used a multi-model ensemble for the SOC modeling (Table 2) which was developed and analyzed in Riggers et al. (2019). In this previous study, Riggers et al. (2019) compared the performance of six different processbased multi-compartment SOC models. The OC inputs were derived from $\mathrm{OC}$ input estimation methods. These empirical equations are used to calculate aboveground and belowground OC input based on crop yields and crop-specific allocation coefficients (Keel et al. 2017). Riggers et al. (2019) selected five OC input estimation methods from the literature and combined them with the SOC models (in total 30 model combinations). They evaluated the model combinations as single model or as multi-model ensemble on a network of 139 agricultural permanent soil monitoring sites in Germany. Thereby, the multi-model ensemble used in the present study showed an absolute mean error of $0.004 \mathrm{Mg} \mathrm{ha}^{-1} \mathrm{a}^{-1}$ and a root mean squared error of $0.56 \mathrm{Mg} \mathrm{ha}^{-1} \mathrm{a}^{-1}$, and performed better than the single model combinations and other ensemble combinations.

The multi-model ensemble consisted of five different SOC models: C-TOOL (Taghizadeh-Toosi et al. 2014), CENTURY (Parton et al. 1994), ICBM (Andrén and Kätterer 1997), ROTH-C (Coleman and Jenkinson 2005) and YASSO07 (Tuomi et al. 2011). Each of these models describes SOC decomposition by first order kinetics and defines different SOC qualities represented by interacting SOC pools. Decomposition rates of model pools are modulated by external factors, e.g. temperature, moisture or soil texture. Models differ with respect to the number of pools, linkage between pools and the factors that modulate decomposition rates (Table S2). Model initialization was done by assuming initial equilibrium conditions using proposed methods from the literature, which have been also applied in Riggers et al. (2019). The original literature contains details on CENTURY (Parton et al. 1994), C-TOOL (Taghizadeh-Toosi et al. 2014), ICBM (Andrén and Kätterer 1997), ROTH-C (Coleman and Jenkinson 2005) and YASSO07 (Tuomi et al. 2011). In brief, CTOOL had three pools in the topsoil (fresh, humified and resistant organic matter), which were initialized with fixed fractions (Taghizadeh-Toosi and Olesen 2016). The used soil organic matter submodule of CENTURY included eight pools: a structural, metabolic and active (microbes) pool in the surface layer and a structural, metabolic, active, slow and passive pool in the soil layer. Initialization was done following Falloon and Smith (2002). The ICBM version was built up of two young and one old organic carbon pool, which were initialized following Andrén and Kätterer (1997). ROTH-C consisted of five different pools: decomposable and resistant plant material, microbial biomass, humified organic matter and inert organic carbon. The pools were initialized by an analytic solution of Dechow et al. (2019). In YASSO07 the organic carbon was separated into five pools based on the chemical quality: soluble in ethanol, soluble in water, hydrolysable in acid, neither soluble nor hydrolysable and recalcitrant humus. The initial pool sizes were quantified by fixed fractions (Riggers et al. 2019). The SOC models were implemented and run in R ( $\mathrm{R}$ Core Team 2018) using the SoilR package (Sierra et al. 2012), as was done in Riggers et al. (2019).

The OC input estimation methods calculated the OC input from different plant compartments (e.g. straw, stubble, roots) based on crop yields and crop-specific parameters. The OC input was then summarized in aboveground and belowground OC input for the SOC models (Riggers et al. 2019). For calculation details on the OC input estimation methods, see bolinder (Bolinder et al. 2007), bze (Jacobs et al. 2018), ccb (Franko et al. 2011) and ipcc-nir (Rösemann et al. 2017).

Soil organic carbon modeling and minimization

The modeling was performed from January 2014 to December 2099 in a monthly time step. The SOC models required an initial SOC stock, climate data and OC input data (Table S2). SOC stocks of the German Agricultural Soil Inventory that were sampled from 2011 to 2018 were shifted to 2014 (mean of the sampling period) and used as initial SOC stocks. The climate variables used in the SOC 

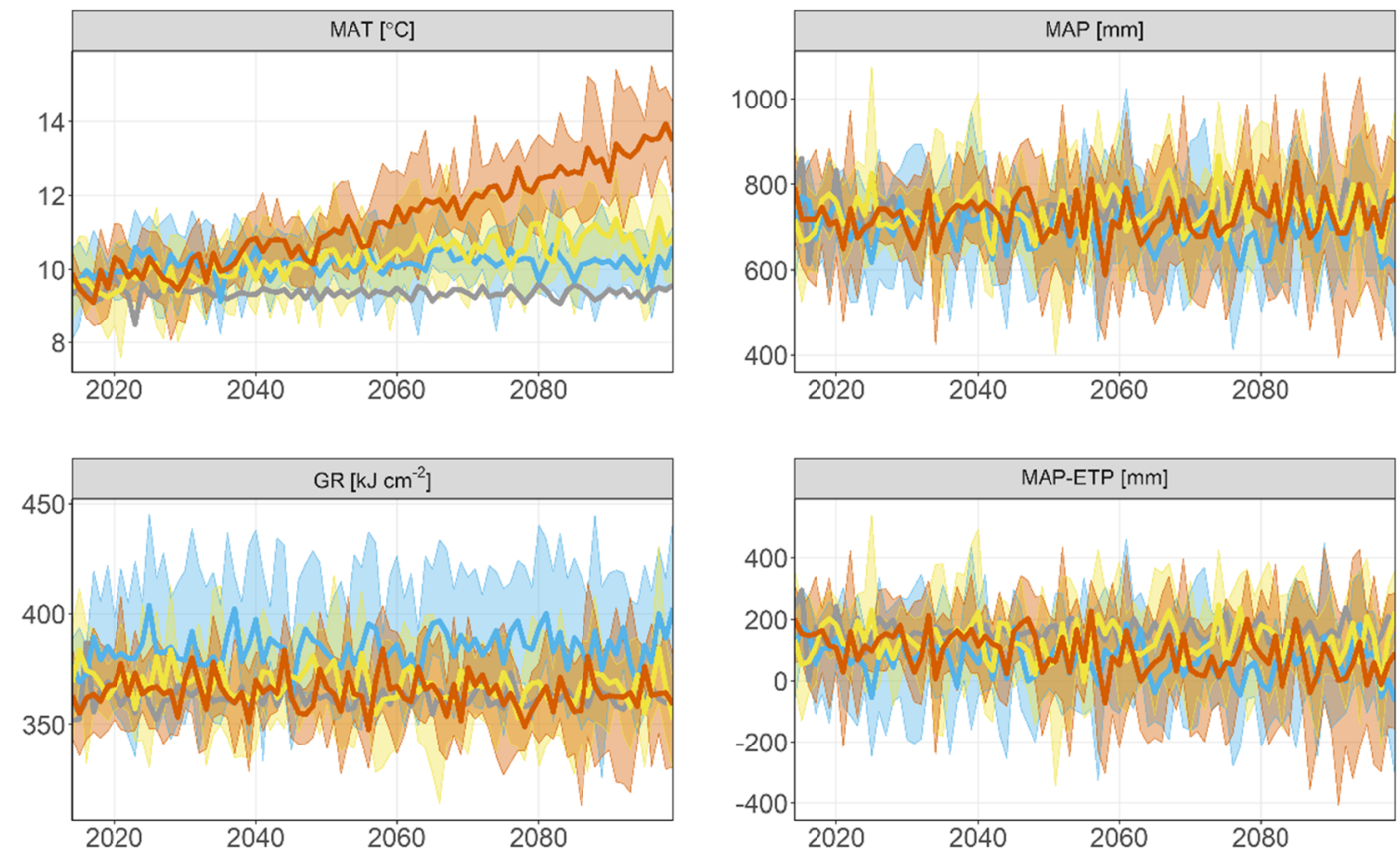

Climate scenario $\square$ no future climate change $\square$ climate change (RCP2.6) $\square$ climate change (RCP4.5) $\square$ climate change (RCP8.5)

Fig. 3 Projected mean annual temperature (MAT), mean annual precipitation (MAP), annual global radiation (GR) and calculated climatic water balance (MAP - potential evapotranspiration (ETP)) for the study area for the period 2014-2099. The climate scenarios covered three climate change scenarios based on different representative concentration pathways (RCPs) plus a scenario

modeling were taken from the four described climate scenarios (three climate change scenarios and one no future climate change scenario). The OC input was derived from the crop yields reported in the German Agricultural Soil Inventory and repeated for each site up to 2099. We constrained the modelling to soil processes and did not simulate potential plant growth responses to climate change.

Table 1 Trends of mean annual temperature (MAT), mean annual precipitation (MAP), annual global radiation (GR) and climatic water balance (MAP - potential evapotranspiration (ETP)) for the study area for the period 2014-2099. The climate scenarios of no future climate change. This figure displays the mean and the $95 \%$ confidence interval summarizing the uncertainty of the climate projections. The scenario of no future climate change was based on repeated measurement data and therefore showed no model uncertainty

The modeling study included three steps (Table 3): (i) calculating the SOC stocks under unchanged climate and current $\mathrm{OC}$ input levels, (ii) calculating the SOC stocks under changed climate and current OC input levels, and (iii) estimating the required $\mathrm{OC}$ input to achieve different predefined SOC stock levels at the end of the century.

covered three climate change scenarios based on different representative concentration pathways (RCPs) and a scenario of no future climate change

\begin{tabular}{lllll}
\hline Climate scenario & $\begin{array}{l}\text { MAT } \\
{\left[{ }^{\circ} \mathrm{C}^{-1}\right]}\end{array}$ & $\begin{array}{l}\text { MAP } \\
{\left[\mathrm{mm} \mathrm{a}^{-1}\right]}\end{array}$ & $\begin{array}{l}\text { GR } \\
{\left[\mathrm{kJ} \mathrm{cm}^{-2} \mathrm{a}^{-1}\right]}\end{array}$ & $\begin{array}{l}\text { MAP-ETP } \\
{\left[\mathrm{mm} \mathrm{a}^{-1}\right]}\end{array}$ \\
\hline No future climate change & $2.9 \mathrm{e}-05$ & -0.039 & -3.185 & -0.036 \\
Climate change (RCP2.6) & $0.003(*)$ & $-0.461(*)$ & 65.198 & $-0.625(*)$ \\
Climate change (RCP4.5) & $0.017(* * *)$ & 0.322 & $-70.788(*)$ & -0.084 \\
Climate change (RCP8.5) & $0.048(* * *)$ & 0.181 & -30.187 & $-1.094(* * *)$ \\
\hline
\end{tabular}

Significance codes of $\mathrm{p}_{\text {slope }}: 0<* * *<0.001<* *<0.01<*<0.05$ 
Table 2 Soil organic carbon (SOC) models and organic carbon (OC) input estimation methods used in the multi-model ensemble

\begin{tabular}{ll}
\hline SOC model & OC input estimation method \\
\hline CENTURY $^{\mathrm{a}}$ & ccb $^{\mathrm{f}}$ \\
& $\begin{array}{l}\text { ipcc-nir } \\
\text { bze }\end{array}$ \\
& bolinder $^{\mathrm{i}}$ \\
C-TOOL $^{\mathrm{b}}$ & ipcc-nir \\
& ccb \\
ICBM $^{\mathrm{c}}$ & ipcc-nir \\
& ccb $^{\mathrm{f}}$ \\
ROTH-C $^{\mathrm{d}}$ & ipcc-nir \\
YASSO07 $^{\mathrm{e}}$ & \\
\hline
\end{tabular}

$\overline{{ }^{a} \text { Parton et al. (1994), }{ }^{\mathrm{b}} \text { Taghizadeh-Toosi et al. (2014), }{ }^{\mathrm{c}} \text { Andrén }}$ and Kätterer (1997), ${ }^{\mathrm{d}}$ Coleman and Jenkinson (2005), ${ }^{\mathrm{e}}$ Tuomi et al. (2011), ${ }^{\mathrm{f}}$ Franko et al. (2011), ${ }^{\mathrm{g}}$ Rösemann et al. (2017),

${ }^{\mathrm{h}}$ Jacobs et al. (2018), ${ }^{\mathrm{i}}$ Bolinder et al. (2007)

\section{Soil organic carbon stocks under current organic} carbon input levels

In the first step, we run the SOC models with unchanged OC input and recent climate data (no future climate change) for each of the 991 sites. This resulted in 8919 SOC stock time series all across Germany (991 sites x 9 SOC model combinations $\mathrm{x} 1$ climate projection). We averaged the results of the 991 sites per climate projection and SOC model combination, resulting in a total of 9 SOC stock time series (9 SOC model combinations x 1 climate projection). We then calculated the average and the standard deviation of the 9 SOC stock time series to receive the ensemble mean. This ensemble mean is further referred to as reference model run. The variability between spatially averaged model estimates represents the model structural uncertainty of the model ensemble (Riggers et al. 2019). Thus, the standard deviation of the ensemble mean represented only the model ensemble uncertainty and not the site-specific variability.

In the second step, we run the SOC models with unchanged $\mathrm{OC}$ input and climate variables according to the three climate change scenarios. This resulted in 142,704 SOC stock time series all across Germany (991 sites x 9 SOC model combinations x 16 climate projections). Again, we first averaged the SOC stock time series of the 991 sites per climate projection and SOC model combination, resulting in a total of 144 SOC stock time series (9 SOC model combinations x 16 climate projections). Of these 144 SOC stock time series, 54 were associated with RCP4.5 and 45 were associated with each of RCP2.6 and RCP8.5. The SOC stock time series were then averaged per climate change scenario to obtain one ensemble SOC stock time series for each climate scenario.

\section{Estimating the required organic carbon input}

We estimated the additional OC input via crop residues required to preserve or increase SOC stocks. In doing so, we increased the aboveground and belowground OC inputs of the study sites equally assuming a linear increase between 2014 and 2099. The relative OC input increase between 2014 and 2099 was determined using one-dimensional optimization. Minimization was performed using the optim function in R with the method "Brent", which is used for one-dimensional problems (Brent 1973). The algorithm minimized the difference between a chosen target SOC stock and the SOC stock of a

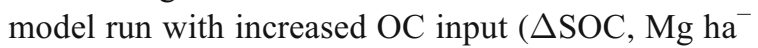
$\left.{ }^{1}\right)$ at the end of the simulation:

$\triangle S O C=S O C_{\text {target }}-\left(\frac{1}{10} \sum_{\mathrm{i}=2090}^{2099} S_{\text {Sinput }, i}\right)$

where $S O C_{\text {target }}$ is the chosen target SOC stock $\left[\mathrm{Mg} \mathrm{ha}^{-1}\right]$ and $S O C_{\text {cinput }}$ is the SOC stock time series of the model run with increased OC input $\left[\mathrm{Mg} \mathrm{ha}^{-1}\right]$. $S O C_{\text {cinput }}$ was averaged first per climate projection and SOC model combination and then per climate change scenario, as it was done above. To avoid errors due to high or low OC input in the last year, the previous 10 years of the ensemble SOC stock time series were averaged for the purposes of minimization. Lower and upper limits of optim were set to a sufficient range but modified individually for each model run to reduce the running time. The default settings of optim were used to stop the algorithm.

We defined three different target SOC stocks for the end of the 21 st century (Table 4, Fig. S2): (1) Reference SOC stock: projected SOC stocks in 2095 (the average for the period 2090-2099) are at the same level as the SOC stock of the reference model run in 2095. (2) Constant SOC stock: projected SOC stocks in 2095 are the same as in 2014. The 2014 SOC stock was thereby the mean of the SOC stocks measured in the first German Agricultural Soil Inventory (2011-2018). (3) 4\%o-increased SOC stock: 
Table 3 Overview of the performed modeling steps with the origin of the climate and the organic carbon (OC) input data used as input data for the soil organic carbon (SOC) models

\begin{tabular}{|c|c|c|c|}
\hline Step & Climate data & OC input data & SOC stock \\
\hline $\begin{array}{l}\text { SOC stocks under current OC input levels } \\
\text { and unchanged climate (Reference model } \\
\text { run) }\end{array}$ & $\begin{array}{l}\text { Reported in the German Agricultural } \\
\text { Soil Inventory }\end{array}$ & $\begin{array}{l}\text { Derived from crop yields reported in } \\
\text { the German Agricultural Soil } \\
\text { Inventory }\end{array}$ & Calculated \\
\hline $\begin{array}{l}\text { SOC stocks under current OC input levels } \\
\text { and changed climate }\end{array}$ & $\begin{array}{l}\text { Derived from RCP2.6, RCP4.5, } \\
\text { RCP8.5 }\end{array}$ & $\begin{array}{l}\text { Derived from crop yields reported in } \\
\text { the German Agricultural Soil } \\
\text { Inventory }\end{array}$ & Calculated \\
\hline Estimating the required $\mathrm{OC}$ input & $\begin{array}{l}\text { Reported in the German Agricultural } \\
\text { Soil Inventory (no future climate } \\
\text { change) } \\
+ \\
\text { Derived from RCP2.6, RCP } 4.5 \text {, } \\
\quad \text { RCP8.5 (climate change) }\end{array}$ & $\begin{array}{l}\text { Estimated via one-dimensional opti- } \\
\text { mization }\end{array}$ & Predefined \\
\hline
\end{tabular}

$\mathrm{RCP}=$ representative concentration pathway

projected SOC stocks in 2095 are increased compared with 2014. Here we increased the SOC stock of 2014 by $34.4 \%$ up to 2099 , assuming an annual linear increase of $4 \%$ o to test the theoretical feasibility of increasing SOC stocks, as promoted in the "4 per 1000 " initiative.

\section{Computations}

Trends in climate (MAT, MAP, GR) and mean annual SOC changes were calculated in R (R Core Team 2018) with linear regressions using the basic $\mathrm{R}$ function $\mathrm{lm}$. The ensemble SOC stock time series and associated uncertainty were calculated for each climate scenario. Here, we first averaged the SOC stock time series of the 991 sites per climate projection and multi-model ensemble member. We then calculated the mean and the $95 \%$ confidence interval (CI) across the climate projections and the multimodel ensemble members. Thus, the 95\% CI showed the model uncertainty of the different climate projections and SOC models. The relationship between SOC stock increase in 2095 and required OC input increase up to 2099 was determined. We thereby estimated the required $\mathrm{OC}$ input increase to raise SOC stocks in 2095 by $0 \%$ (Constant SOC stock), $10 \%, 20 \%$ and $34.4 \%$ (4\%o-increased SOC stock) and fitted linear models ( $\mathrm{lm}$ in R) grouped for the four climate scenarios. All figures were created using ggplot2 (Wickham 2009).

\section{Results}

Projected soil organic carbon stocks up to 2099 under current OC input levels

On average, the models estimated declining SOC stocks for German croplands in the period 2014-2099, but revealed a large $95 \% \mathrm{CI}$ (Fig. 4). The decline was more pronounced for the climate change scenario under RCP8.5 than under RCP2.6. Projected SOC stocks declined by $10 \%$ from current SOC stock $\left(58.1 \mathrm{Mg} \mathrm{ha}^{-1}\right)$ to an average level of $52.5 \mathrm{Mg} \mathrm{ha}^{-1}$ [95\% CI: $46.0 \mathrm{Mg}$ $\mathrm{ha}^{-1} ; 59.0 \mathrm{Mg} \mathrm{ha}^{-1}$ ] for no future climate change and $52.1 \mathrm{Mg} \mathrm{ha}^{-1}$ [43.9 $\left.\mathrm{Mg} \mathrm{ha}^{-1} ; 60.4 \mathrm{Mg} \mathrm{ha}^{-1}\right]$ for RCP2.6, and appeared to approximate a new steady state. Projected SOC stocks for climate change scenarios RCP4.5 and RCP8.5 declined even more drastically by between $14 \%$ and $18 \%$ to a level of $50.1 \mathrm{Mg} \mathrm{ha}^{-1}$ [43.6 Mg ha ${ }^{-1} ; 57.0 \mathrm{Mg} \mathrm{ha}^{-1}$ ] and $47.8 \mathrm{Mg} \mathrm{ha}^{-1}$ [39.3 $\mathrm{Mg} \mathrm{ha}^{-1} ; 57.4 \mathrm{Mg} \mathrm{ha}^{-1}$ ] respectively. Thus, without changes in OC input, estimated SOC stocks declined up to the end of the 21st century by between 10 and $18 \%$, representing an average annual SOC loss of between 0.065 and $0.120 \mathrm{Mg} \mathrm{ha}^{-1} \mathrm{a}^{-1}$.

SOC losses were highest in the first 10 years and declined up to 2099 (Table 5). For the climate change scenario RCP8.5, SOC change rates were fairly constant from the period 2024-2037 onwards, which might be due to the strong non-linear warming in this climate scenario (Fig. 3). The changes in annual SOC losses during the 86 -year period were especially pronounced 
Table 4 Overview of the targeted mean soil organic carbon (SOC) stocks used in the minimization

\begin{tabular}{lll}
\hline Target name & Description & $\begin{array}{l}\mathrm{SOC}_{\text {target }} \\
{\left[\mathrm{Mg} \mathrm{ha}^{-1}\right]}\end{array}$ \\
\hline $\begin{array}{c}\text { Reference SOC } \\
\text { stock }\end{array}$ & $\begin{array}{c}\text { Projected SOC stocks in 2095 are } \\
\text { at the same level as the SOC } \\
\text { stock of the reference model } \\
\text { run in 2095. }\end{array}$ \\
$\begin{array}{c}\text { Projected SOC stocks in 2095 are } \\
\text { the same as in 2014. }\end{array}$ \\
$\begin{array}{c}\text { Projected SOC stocks in 2095 are } \\
\text { stock }\end{array}$ & 78.1 \\
SOC-increased stock & increased by 34.4\% compared \\
& with 2014. \\
\hline
\end{tabular}

NB: 2095 refers to the average for the period 2090-2099

for climate change scenario RCP2.6 and the scenario of no future climate change, with a decline of nearly $88 \%$. This, together with the low SOC change rates of $0.026 \mathrm{Mg} \mathrm{ha}{ }^{-1} \mathrm{a}^{-1}$ (no future climate change) and $0.025 \mathrm{Mg} \mathrm{ha}^{-1} \mathrm{a}^{-1}$ (RCP2.6) in the period 2057-2099, might indicate that both are moving towards a new steady state after that period. However, the SOC change rate for the climate change scenario RCP8.5 decreased only by $53 \%$, showing an ongoing high loss of SOC at the end of the 21 st century.

\section{Estimated required total organic carbon input in 2099}

The total OC input from crop residues in the reference model run was $2.7 \mathrm{Mg} \mathrm{ha}^{-1}$ on average in 2095 (the annual average for the period 2090-2099). As the total OC input in the reference model run did not change with time, this value represents the current total OC input level for the 991 German cropland sites studied. The total OC input would need to increase by $+5 \%$ to + $283 \%$, depending on the climate scenario and target (Table 6), in order to achieve the three chosen targets. Thus, the estimated required total OC input in 2095 varied between $2.8 \mathrm{Mg} \mathrm{ha}^{-1}$ and $9.8 \mathrm{Mg} \mathrm{ha}^{-1}$ (Fig. 5). In the model runs referring to the reference SOC stock, the annual total $\mathrm{OC}$ input increases required were low (0.002 $\mathrm{Mg} \mathrm{C} \mathrm{ha-1} \mathrm{a}^{-1}$ to $0.013 \mathrm{Mg} \mathrm{C} \mathrm{ha}^{-1} \mathrm{a}^{-1}$ ), resulting in an estimated $\mathrm{OC}$ input of $2.8 \mathrm{Mg} \mathrm{ha}^{-1}$ (RCP2.6), 3.2 $\mathrm{Mg} \mathrm{ha}^{-1}$ (RCP4.5) and 3.7 $\mathrm{Mg} \mathrm{ha}^{-1}$ (RCP8.5) in 2095. It should be noted that the reference SOC stock in 2095 was lower than the current SOC stock in 2014, and estimated OC input increases would only compensate for future climate change-driven SOC losses in this target. A minimum increase in total OC input of $45 \%$ in 86 years would be needed to maintain SOC stocks in 2095 at the 2014 SOC stock level (constant SOC stock). In the case of climate change scenario RCP8.5, the required total OC input in 2095 would be nearly double $\left(5.0 \mathrm{Mg} \mathrm{ha}^{-1}\right)$ of the current input. An even more drastic increase in total OC input would be necessary to raise SOC stocks annually by $4 \%$ from $58.1 \mathrm{Mg} \mathrm{ha}^{-1}$ (2014) to $78.1 \mathrm{Mg} \mathrm{ha}^{-1}$ (2099). In this case, the required total OC inputs were more than three times the current total OC input, ranging in 2095 from 8.2 $\mathrm{Mg} \mathrm{ha}^{-1}$ (RCP2.6) to $9.8 \mathrm{Mg} \mathrm{ha}^{-1}$ (RCP8.5). The relative SOC stock increase between 2014 and 2099 was linearly correlated to the required relative OC input increase in this period (Fig. S3), because decomposition is described by first order kinetics in all models. The slopes of this linear correlation did not vary very much between climate scenarios, but nonetheless indicated that greater climate change would require a higher OC input to increase SOC stocks by the same amount compared with no future climate change.

\section{Discussion}

Projected changes in soil organic carbon stocks in German cropland

Under current OC input levels, modeled SOC stocks of German cropland showed a declining trend up to the end of the century. These results are in line with the study by Wiesmeier et al. (2016) for Bavaria, which modeled a $16 \%$ decline in SOC stocks for croplands in the $21 \mathrm{st}$ century with a mean temperature increase of $+3.3{ }^{\circ} \mathrm{C}$ (SRES-A1B) and unchanged OC input, while we modeled a decline in SOC stocks of $14 \%$ (RCP4.5) and $18 \%(\mathrm{RCP} 8.5)$ with a temperature increase of + $1.7{ }^{\circ} \mathrm{C}$ and $+3.7^{\circ} \mathrm{C}$ and unchanged $\mathrm{OC}$ input. For European croplands, Smith et al. (2005) estimated SOC losses of between $10 \%$ and $14 \%$ up to 2080 compared with the average cropland SOC stock in 1990 without considering changes in net primary production. Given that these losses are an average value across Europe, with higher losses in the north, our slightly higher SOC losses fit well with the modeling result of Smith et al. (2005). Moreover, the projected SOC change rates for the timespan 2014-2023 are in 


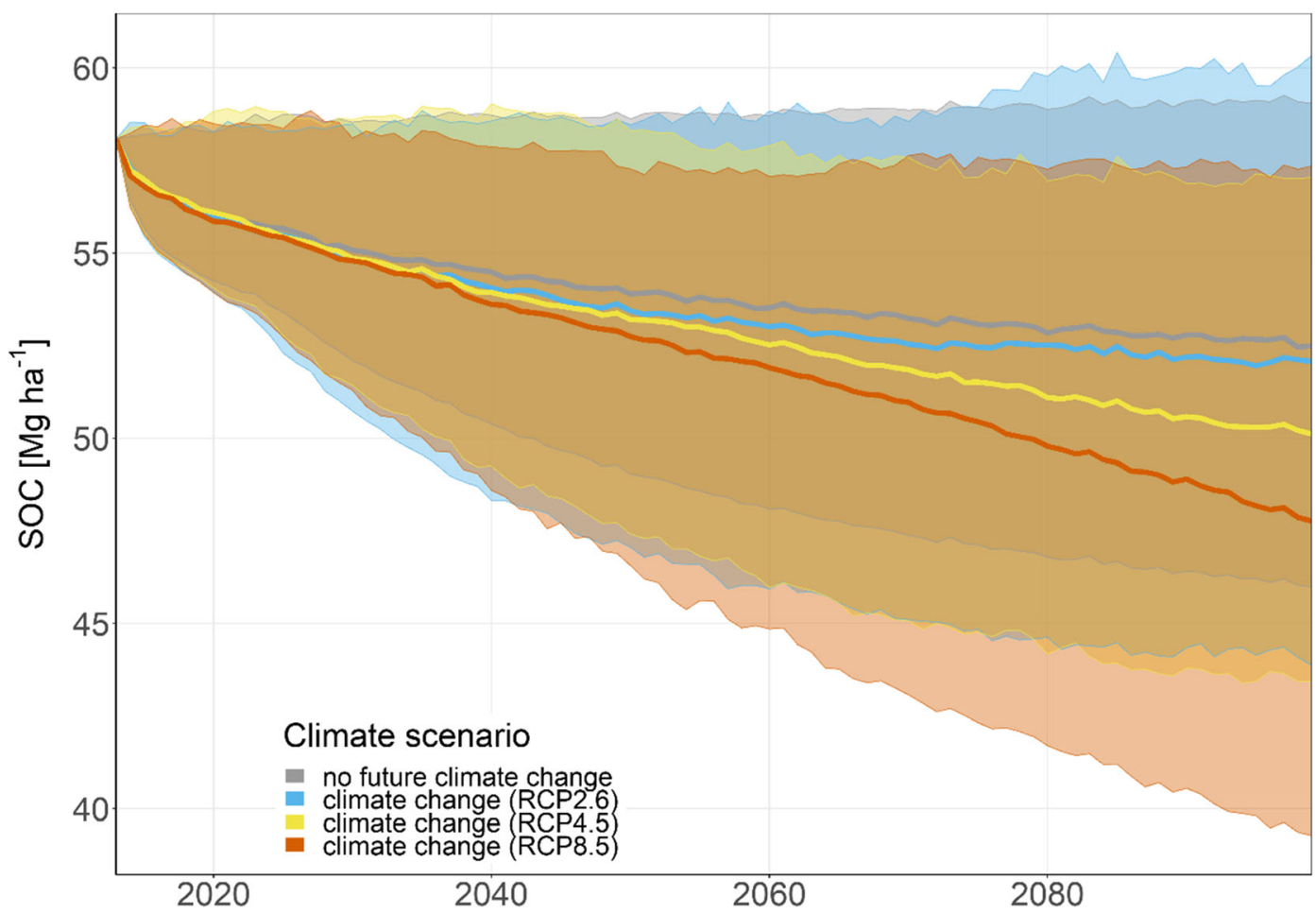

Fig. 4 Projected mean soil organic carbon (SOC) stocks for German croplands under current organic carbon input levels and the $95 \%$ confidence interval for the ensemble of climate projections and SOC models. The climate scenarios covered three

good agreement with the SOC change rates of 139 permanent soil monitoring sites for German croplands for the last 20 years, which showed an average SOC loss of $-0.23 \mathrm{MgC} \mathrm{ha}^{-1} \mathrm{a}^{-1}$ (Jacobs et al. 2018).

The reasons for the projected decline in German cropland SOC stocks even without future climate change could be manifold, such as the effects of past climate change, changes in management practices or land use changes. The long-term (1981-2010) MAT and MAP of the 991 sites increased by $0.64{ }^{\circ} \mathrm{C}$ and $32 \mathrm{~mm}$ on average compared with the long-term MAT climate change scenarios based on different representative concentration pathways (RCPs) and a scenario of no future climate change

and MAP of the reference period 1961-1990 (DWDCDC 2018a, b, c, d). At the same time, OC inputs to the soil could have increased due to increasing yields in the past 60 years (Wiesmeier et al. 2014). Thus, increased OC input could have compensated for the effects of climate change. However, this would only be true if belowground OC inputs were correlated to yield, which is questioned in some recent studies (Hirte et al. 2018; $\mathrm{Hu}$ et al. 2018) and belowground residues are not decreasing with breeding progress (Siddique et al. 1990), especially if the aboveground residues are removed. In

Table 5 Soil organic carbon (SOC) change rates with standard errors for different timespans for the climate scenarios of no future climate change and climate change based on the representative concentration pathways (RCPs) RCP2.6, RCP4.5 and RCP8.5

\begin{tabular}{lllll}
\hline Climate scenario & \multicolumn{2}{l}{ SOC change rate $\left[\mathrm{Mg} \mathrm{ha}^{-1} \mathrm{a}^{-1}\right]$} & & \\
\cline { 2 - 5 } & $2014-2023$ & $2024-2037$ & $2038-2056$ & $2057-2099$ \\
\hline No future climate change & $-0.218 \pm 0.030$ & $-0.088 \pm 0.005$ & $-0.049 \pm 0.002$ & $-0.026 \pm 0.001$ \\
Climate change (RCP2.6) & $-0.225 \pm 0.028$ & $-0.099 \pm 0.005$ & $-0.061 \pm 0.003$ & $-0.025 \pm 0.001$ \\
Climate change (RCP4.5) & $-0.209 \pm 0.027$ & $-0.101 \pm 0.004$ & $-0.067 \pm 0.002$ & $-0.064 \pm 0.001$ \\
Climate change (RCP8.5) & $-0.223 \pm 0.031$ & $-0.110 \pm 0.003$ & $-0.093 \pm 0.002$ & $-0.104 \pm 0.001$ \\
\hline
\end{tabular}


Table 6 Required organic carbon (OC) input increase in 2099 compared with 2014 and corresponding yearly OC input increase. The required OC input was estimated for three target soil organic

\begin{tabular}{|c|c|c|c|}
\hline Target name & Climate scenario & $\begin{array}{l}\text { Required OC input increase in } 2099 \\
\text { compared with } 2014 \text { [\%] }\end{array}$ & $\begin{array}{l}\text { Required yearly OC input } \\
\text { increase }\left[\mathrm{Mg} \mathrm{C} \mathrm{ha-1} \mathrm{a}^{-1}\right]\end{array}$ \\
\hline \multirow[t]{3}{*}{ Reference SOC stock } & Climate change (RCP2.6) & 5 & 0.002 \\
\hline & Climate change (RCP4.5) & 20 & 0.006 \\
\hline & Climate change (RCP8.5) & 41 & 0.013 \\
\hline \multirow[t]{4}{*}{ Constant SOC stock } & No future climate change & 45 & 0.014 \\
\hline & Climate change (RCP2.6) & 51 & 0.016 \\
\hline & Climate change (RCP4.5) & 69 & 0.021 \\
\hline & Climate change (RCP8.5) & 93 & 0.029 \\
\hline \multirow[t]{4}{*}{ 4\%o-increased SOC stock } & No future climate change & 213 & 0.066 \\
\hline & Climate change (RCP2.6) & 221 & 0.068 \\
\hline & Climate change (RCP4.5) & 246 & 0.076 \\
\hline & Climate change (RCP8.5) & 283 & 0.088 \\
\hline
\end{tabular}

carbon (SOC) stocks. The climate scenarios covered three climate change scenarios based on different representative concentration pathways (RCPs) and a scenario of no future climate change

Required OC input increase in $2099 \quad$ Rearly OC input compared with 2014 [\%]

Smith et al. 2007). Soils under permanent grassland and forest have higher SOC stocks than soils under arable land (Freibauer et al. 2004; Jacobs et al. 2018; Poeplau et al. 2011). Thus, when converting these sites into cropland, a new equilibrium of SOC stocks develops

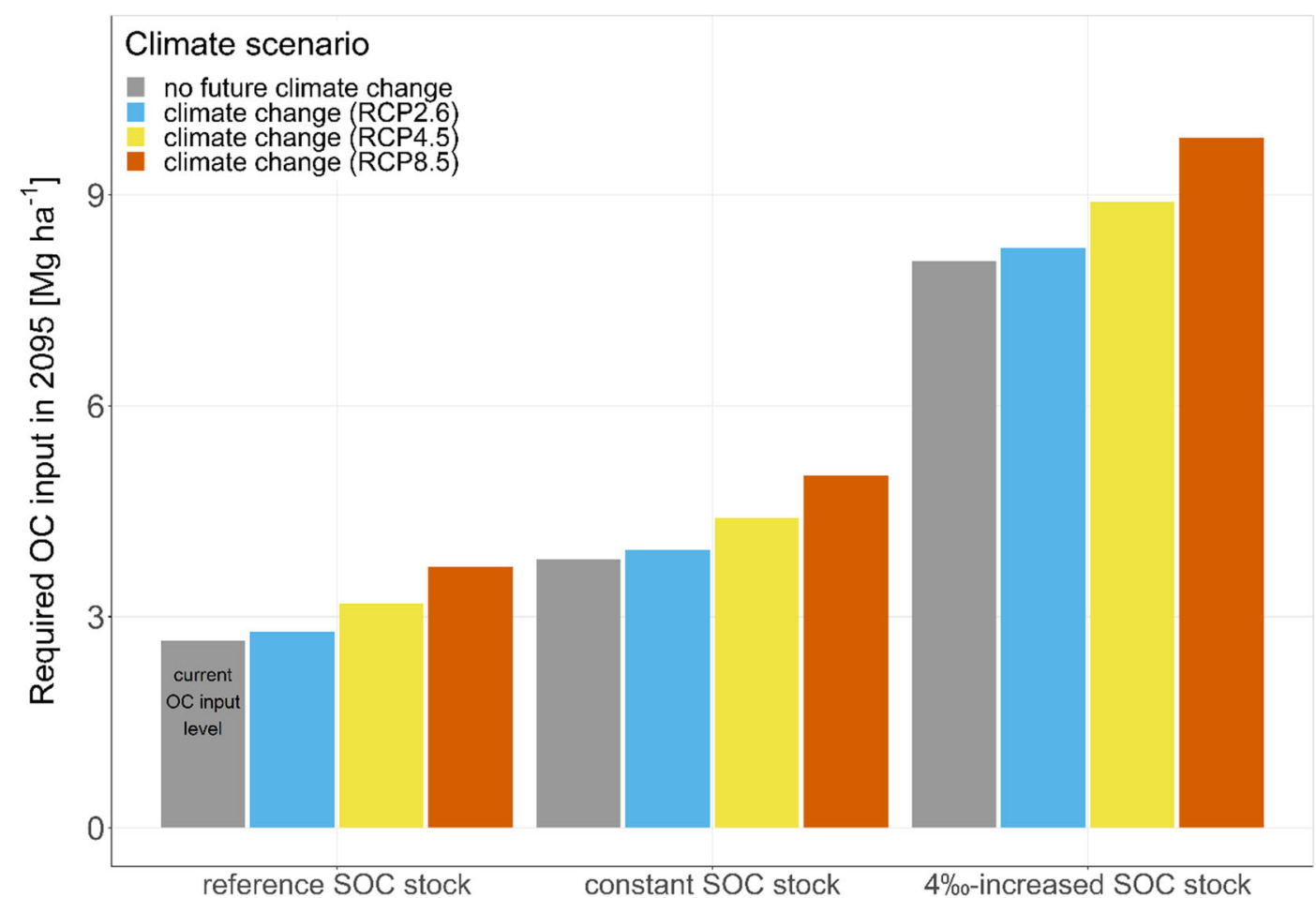

Fig. 5 Mean estimated required organic carbon (OC) input for the last decade of the modeling period (2090-2099) for the three target soil organic carbon (SOC) stocks. The climate scenarios covered three climate change scenarios based on different representative concentration pathways (RCPs) and a scenario of no future climate change 
that is lower than before. It is not easy to separate out sites that have experienced land use change in the past. Land use in Germany has partly been documented in historical maps, which can date back to 1800 depending on the federal state. Based on these maps and farmers' questionnaires in the German Agricultural Soil Inventory (Jacobs et al. 2018), land use changes were presumed for 138 sites (14\%) since 1900, and for 118 sites (12\%) since 1950 . More than $85 \%$ of these sites were formerly used as grassland. Accordingly, some of the sites might still lose OC, but the declining SOC trend was found for more than this fraction of affected sites. When omitting sites with reported land use change, (i) ensemble SOC stocks were lower in all four climate scenarios under current OC input levels, and (ii) SOC change rates for the first ten years were still negative, but were 14\% lower than the complete dataset of 991 sites. However, the historical maps only provide snapshots and there is no guarantee that the land use was constant in the years between map publications. It is likely that more than $14 \%$ of the sites underwent land use change in the last 100 years. In addition, a change in farming system or, more specifically, changes in input of organic matter can alter SOC stocks on arable land ( $\mathrm{Hu}$ et al. 2018; Johnston et al. 2009; Leifeld and Fuhrer 2010). However, sites where land use and management changes had been identified were not removed from the modeling since the intention was to provide a realistic picture of the development of SOC stocks in German croplands.

Projected SOC stocks for German croplands and thus the estimated OC input increases were associated with large uncertainties resulting from nine combinations of SOC models and OC input estimation methods and five to six different climate projections. Soil organic carbon dynamics are complex and yet it is not clear, how soils react to a warmer environment (Bradford et al. 2016) and if this reaction changes in the long term (Carey et al. 2016; Melillo et al. 2017; Romero-Olivares et al. 2017). There is a wide range of sensitivities of decomposition to temperature estimated from laboratory and field experiments and the range of sensitivities is still a matter of debate, which is also true for the temperature response functions implemented in models (Todd-Brown et al. 2018). Sulman et al. (2018) compared the response to warming and litter additions for different SOC model concepts and field manipulation experiments and found a similar variability for models and experiments. Moreover, the experiments showed SOC gains and losses and were not sufficient to validate model outcomes (Sulman et al. 2018). Abramoff et al. (2019) found similar results and concluded that measured total SOC changes did not help to evaluate the temperature sensitivity of mineral sorption and/or microbial activity. Bradford et al. (2016) suggest representing these structural uncertainties with multi-model ensembles to increase the confidence of the model predictions. In the present multi-model ensemble, the SOC models showed different temperature responses (Fig. S4). In addition, soil moisture also influences decomposition rates (Ise and Moorcroft 2006). The response to changing moisture conditions reduced the temperature effects on decomposition rates in some of the models. However, not all the models included a moisture response (Riggers et al. 2019). These arguments collectively support the strength of a multimodel ensemble compared with a single model (Hagedorn et al. 2005; Tebaldi and Knutti 2007), as it averages a range of possible temperature and moisture responses and provides information about resulting uncertainties.

In summary, SOC stocks in German croplands are predicted to decline under climate change when considering current $\mathrm{OC}$ input levels and management. Soil warming experiments have revealed that temperature sensitivity might be highly variable and that the temperature response of the decomposition rate under long-term warming might be changing. Thus, the use of multi-models is useful in order to take this uncertainty into consideration. However, the full range of possible biotic and abiotic responses in the soil to climate change might not be covered by the models used.

Estimated required changes in carbon input in the 21st century

Based on climate projections and SOC models we estimated future needs of OC input development to preserve or increase carbon stocks of agricultural soils in Germany. Our simulations suggest that an OC input increase of 5 to $41 \%$ up to 2095 is needed to maintain the reference SOC stock and thus compensate for future climate change-driven SOC losses. There are considerable uncertainties associated with the extrapolation of plant growth into the future (Asseng et al. 2013; lizumi et al. 2017). Estimated yield changes depend significantly on the chosen influence factors, which mainly include climatic variables (temperature, precipitation), atmospheric $\mathrm{CO}_{2}$ concentration, and management adaptations 
(Asseng et al. 2013; Deryng et al. 2014; Ewert et al. 2005). Ewert et al. (2005) estimated changes in crop productivity for Europe based on climate change, atmospheric $\mathrm{CO}_{2}$ levels and technology development. They estimated increases in crop productivity of $+163 \%$ for the global economic and fossil fuel intensive world (Special Report on Emissions Scenarios (SRES), A1F1) and $+43 \%$ for the regional environmental world (SRES B2) for the period 2000-2080 when considering all three factors together. Where the estimation was only based on climate change, yields decreased slightly or remained constant up to 2080 (Ewert et al. 2005). Müller and Robertson (2014) even estimated yields as decreasing by $12-21 \%$ (wheat) and $10-38 \%$ (maize) from 2000 to 2050 for the climate scenario RCP8.5 when just considering climate factors and leaving out $\mathrm{CO}_{2}$ fertilization effects. Kersebaum and Nendel (2014) simulated positive wheat yield changes $(0.9-6.0 \%)$ for Germany between the reference period (1961-1990) and a future period (2021-2050) in response to climate change (SRES-A1B) and elevated $\mathrm{CO}_{2}$, but the response varied across regions and was influenced by soil properties. As in the other studies, they also found decreasing (-16\%) yields when neglecting the $\mathrm{CO}_{2}$ effect (Kersebaum and Nendel 2014). The effect of technology development, especially breeding, outweighed the effects of climate change and rising $\mathrm{CO}_{2}$ concentration in the study of Ewert et al. (2005). Furthermore, also declining SOC stocks might affect yields, potentially inducing a feedback loop, since both are interlinked through soil fertility (Henryson et al. 2018; Wiesmeier et al. 2015). However, with reference to SOC it will be important that not only yield but also carbon input is enhanced. This is not necessarily the case when crop yields are increased, e.g. due to changes in harvest index (Freibauer et al. 2004). Also Taghizadeh-Toosi et al. (2016) and Hirte et al. (2018) recently showed, that root biomass of crops is not necessarily a function of shoot biomass. If the required OC input increase would come from increasing aboveground biomass only, the required increase in $\mathrm{OC}$ input to achieve the reference SOC stock and compensate for future climate change-driven SOC losses needs to be higher (10-93\%, Fig. S5). This is because roots contribute more to stabilized SOC than aboveground residues (Kätterer et al. 2011) which is considered by some members of the model ensemble.

Although associated with some uncertainties elevated $\mathrm{CO}_{2}$ levels and breeding may well lead to an increase in plant growth and subsequent greater OC input. However, if SOC losses are not only compensated for but SOC stocks are also increased, the introduction of additional management actions will be required. For example, Poeplau and Don (2015) suggest replacing bare fallow with cover crops during the winter period to sequester more $\mathrm{OC}$ in agricultural soils. Moreover, with rising temperatures thermal growing seasons also lengthen (Ruosteenoja et al. 2016), leading to an increase in the thermal growing season by +15 to + 90 days in Germany by the end of the century (20712100) (https://www.regionaler-klimaatlas.de, accessed 15.08.2019). A longer thermal growing season of up to three months might offer the opportunity, with a sufficient water supply, to add a further crop into the rotation, thus having three crops in two years, which would lead to a higher OC input. There are many other management options such as residue retention, integrated nutrient management, improved crop rotation, agroforestry, mixed crop-livestock farming systems, biochar application to soil or clay addition to sandy soils that seem to be promising ways of enhancing SOC stocks (Singh et al. 2018). Besides increased OC input, also the availability of sufficient nitrogen for additional SOC storage needs to be ensured (Hungate et al. 2003). This is of particular importance under elevated atmospheric $\mathrm{CO}_{2}$ concentration, which has been shown to increase $\mathrm{C} / \mathrm{N}$ ratios of plant tissues (Gill et al. 2002; Luo et al. 2004). However, the chosen management options should be evaluated with respect to their environmental, societal and economical effects. Reported SOC change rates of mentioned agricultural management practices range up to $\sim 1 \mathrm{MgC} \mathrm{ha}^{-1} \mathrm{a}^{-1}$ (Freibauer et al. 2004). This is considerably higher than the projected climate change-driven SOC losses (Table 5). Therefore, an overcompensation of those losses by appropriate agricultural management, i.e. carbon sequestration under climate change, is certainly feasible at farm level. However, at the national level, it will be more difficult to reach that goal, since climate change is affecting all soils, while improved management will most likely only be conducted on some.

An increase in OC input of 213 to $283 \%$, corresponding to an OC input of 8.1-9.8 $\mathrm{MgC} \mathrm{ha}^{-1} \mathrm{a}^{-1}$, in order to increase SOC stocks annually by $4 \%$ oup to end of the century seems unrealistic. Even if SOC stocks under climate change scenario RCP8.5 were increased by 4 per 1000 only for the next 25 years followed by management to preserve SOC, high OC inputs $\left(8.3 \mathrm{Mg} \mathrm{ha}^{-1}\right.$ 
$\mathrm{a}^{-1}$ from 2038 onwards) would be required (data not shown). Chenu et al. (2019) used Roth-C to estimate the additional OC input to increase SOC stocks (equilibrium) by $8 \%$ in 20 years for a set of pedoclimatic conditions. In contrast, they calculated an additional OC input of $24 \%$ for temperate crops on sandy soils and $29 \%$ on clayey soils. These values are much smaller compared to the required OC input increase of $207 \%$ estimated in the extra simulation mentioned above. This difference might be explained by the fact that the SOC stocks in Chenu et al. (2019) were in equilibrium, while the modeled SOC stocks in our study are not. It stresses, that an increase of SOC stocks requires a compensation of SOC losses first. Moreover, Wiesmeier et al. (2017) concluded that a SOC stock increase of 4 per 1000 is not possible for Bavaria. Instead, they estimated, without considering climate change, that a SOC stock increase of 1.2 per 1000 is achievable for Bavaria if considerable changes in agricultural management are implemented (Wiesmeier et al. 2017).

To conclude, future SOC dynamics in German agricultural soils under climate change are associated with considerable uncertainties, which are more robustly represented with multi-model ensembles. In the literature, contrasting results are found when extrapolating plant growth into the future. Nevertheless, it appears possible that projected warming-induced SOC losses could be compensated for at least in part by future enhanced plant growth, while the preservation and increase of current SOC stocks would require more effort and adaptations of land management. Increasing SOC stocks, which is currently discussed as a negative emission technology, appears to be challenging for German agricultural soils due to the effects of climate change and the legacy of former land use and management.

Supplementary Information The online version contains supplementary material available at https://doi.org/10.1007/s11104020-04806-8.

Acknowledgements This study was funded by the German Federal Ministry of Food and Agriculture as part of the German Agricultural Soil Inventory. The soil dataset used in this study is available in the OpenAgrar repository, https://doi.org/10.3220 /DATA20200203151139.

Funding Open Access funding enabled and organized by Projekt DEAL.

\section{Compliance with ethical standards}

Conflict of interest The authors declare that they have no conflict of interest.

Open Access This article is licensed under a Creative Commons Attribution 4.0 International License, which permits use, sharing, adaptation, distribution and reproduction in any medium or format, as long as you give appropriate credit to the original author(s) and the source, provide a link to the Creative Commons licence, and indicate if changes were made. The images or other third party material in this article are included in the article's Creative Commons licence, unless indicated otherwise in a credit line to the material. If material is not included in the article's Creative Commons licence and your intended use is not permitted by statutory regulation or exceeds the permitted use, you will need to obtain permission directly from the copyright holder. To view a copy of this licence, visit http://creativecommons.org/licenses/by/4.0/.

\section{References}

Abramoff RZ, Torn MS, Georgiou K, Tang JY, Riley WJ (2019) Soil organic matter temperature sensitivity cannot be directly inferred from spatial gradients. Global Biogeochem Cycles 33:761-776. https://doi.org/10.1029/2018gb006001

Andrén O, Kätterer T (1997) ICBM: The introductory carbon balance model for exploration of soil carbon balances Ecol Appl 7:1226-1236. https://doi.org/10.1890/1051-0761(1997 )007[1226:ITICBM]2.0.CO;2

Asseng $\mathrm{S}$ et al (2013) Uncertainty in simulating wheat yields under climate change. Nat Clim Change 3:827-832. https://doi. org/10.1038/Nclimate1916

Bellamy PH, Loveland PJ, Bradley RI, Lark RM, Kirk GJD (2005) Carbon losses from all soils across England and Wales 1978-2003. Nature 437:245-248. https://doi. org/10.1038/nature04038

Bolinder MA, Janzen HH, Gregorich EG, Angers DA, VandenBygaart AJ (2007) An approach for estimating net primary productivity and annual carbon inputs to soil for common agricultural crops in Canada. Agric Ecosyst Environ 118:29-42. https://doi.org/10.1016/j. agee.2006.05.013

Bradford MA, Wieder WR, Bonan GB, Fierer N, Raymond PA, Crowther TW (2016) Managing uncertainty in soil carbon feedbacks to climate change. Nat Clim Change 6:751-758. https://doi.org/10.1038/Nclimate3071

Brent RP (1973) Algorithms for minimization without derivatives. Prentice-Hall, Englewood Cliffs

Capriel P (2013) Trends in organic carbon and nitrogen contents in agricultural soils in Bavaria (south Germany) between 1986 and 2007. Eur J Soil Sci 64:445-454. https://doi.org/10.1111 /ejss. 12054

Carey JC et al (2016) Temperature response of soil respiration largely unaltered with experimental warming. Proc Natl Acad Sci USA 113:13797-13802. https://doi.org/10.1073 /pnas. 1605365113 
Chenu C, Angers DA, Barre P, Derrien D, Arrouays D, Balesdent J (2019) Increasing organic stocks in agricultural soils: Knowledge gaps and potential innovations. Soil Till Res 188:41-52. https://doi.org/10.1016/j.still.2018.04.011

Coleman K, Jenkinson DS (2005) ROTHC-26.3: A model for the turnover of carbon in soil: Model description and windows users guide. IACR Rothamsted, Harpenden

Conant RT et al (2011) Temperature and soil organic matter decomposition rates - synthesis of current knowledge and a way forward. Global Change Biol 17:3392-3404. https://doi. org/10.1111/j.1365-2486.2011.02496.x

Dechow R, Franko U, Kätterer T, Kolbe H (2019) Evaluation of the RothC model as a prognostic tool for the prediction of SOC trends in response to management practices on arableland. Geoderma 337:463-478. https://doi.org/10.1016 /j.geoderma.2018.10.001

Deryng D, Conway D, Ramankutty N, Price J, Warren R (2014) Global crop yield response to extreme heat stress under multiple climate change futures. Environ Res Lett 9. https://doi.org/10.1088/1748-9326/9/3/034011

DWD Climate Data Center (CDC) (2018a) Grids of multi-annual mean precipitation height over Germany 1961-1990, version v1.0. Retrieved from http://opendata.dwd.de/climate environment/CDC/grids_germany/multi ${ }_{-}^{-}$ annual/precipitation/

DWD Climate Data Center (CDC) (2018b) Grids of the multiannual mean temperature (2 m) over Germany 1961-1990, version v1.0. Retrieved from http://opendata.dwd. de/climate_environment/CDC/grids_germany/multi_ annual/air_temperature_mean/

DWD Climate Data Center (CDC) (2018c) Multi-annual grids of precipitation height over Germany 1981-2010, version v1.0. Retrieved from http://opendata.dwd.de/climate_ environment/CDC/grids_germany/multi annual/precipitation/

DWD Climate Data Center (CDC) (2018d) Multi-annual means of grids of air temperature (2 m) over Germany 1981-2010, version v1.0. Retrieved from http://opendata.dwd. $\mathrm{de} / \mathrm{climate}$ environment/CDC/grids_germany/multi annual/air_temperature_mean/

Ewert F, Rounsevell MDA, Reginster I, Metzger MJ, Leemans R (2005) Future scenarios of European agricultural land use I. Estimating changes in crop productivity. Agric Ecosyst Environ 107:101-116. https://doi.org/10.1016/j. agee.2004.12.003

Falloon P, Smith P (2002) Simulating SOC changes in long-term experiments with RothC and CENTURY: model evaluation for a regional scale application. Soil Use Manag 18:101-111. https://doi.org/10.1079/Sum2001108

Franko U, Kolbe H, Thiel E, Liess E (2011) Multi-site validation of a soil organic matter model for arable fields based on generally available input data. Geoderma 166:119-134. https://doi.org/10.1016/j.geoderma.2011.07.019

Freibauer A, Rounsevell MDA, Smith P, Verhagen J (2004) Carbon sequestration in the agricultural soils of Europe. Geoderma 122:1-23. https://doi.org/10.1016/j. geoderma.2004.01.021

Gill RA, Polley HW, Johnson HB, Anderson LJ, Maherali H, Jackson RB (2002) Nonlinear grassland responses to past and future atmospheric CO2. Nature 417:279-282. https://doi.org/10.1038/417279a
Gottschalk P et al (2012) How will organic carbon stocks in mineral soils evolve under future climate? Global projections using RothC for a range of climate change scenarios. Biogeosciences 9:3151-3171. https://doi.org/10.5194/bg-93151-2012

Hagedorn R, Doblas-Reyes FJ, Palmer TN (2005) The rationale behind the success of multi-model ensembles in seasonal forecasting - I basic concept. Tellus A 57:219-233. https://doi.org/10.1111/j.1600-0870.2005.00103.x

Heikkinen J, Ketoja E, Nuutinen V, Regina K (2013) Declining trend of carbon in Finnish cropland soils in 1974-2009. Global Change Biol 19:1456-1469. https://doi.org/10.1111 /gcb. 12137

Henryson K, Sundberg C, Katterer T, Hansson PA (2018) Accounting for long-term soil fertility effects when assessing the climate impact of crop cultivation. Agric Syst 164:185192. https://doi.org/10.1016/j.agsy.2018.03.001

Hirte J, Leifeld J, Abiven S, Oberholzer HR, Mayer J (2018) Below ground carbon inputs to soil via root biomass and rhizodeposition of field-grown maize and wheat at harvest are independent of net primary productivity. Agric Ecosyst Environ 265:556-566. https://doi.org/10.1016/j. agee.2018.07.010

Höper H, Meesenburg H (2012) Stoffgehalte und -vorräte im Boden und deren Veränderungen. In: Höper $\mathrm{H}$, Meesenburg H (ed.) 20 Jahre Bodendauerbeobachtung in Niedersachsen, GeoBerichte 23, LBEG, Hannover, pp 56-69

$\mathrm{Hu}$ T, Sorensen P, Wahlstrom EM, Chirinda N, Sharif B, Li XX, Olesen JE (2018) Root biomass in cereals, catch crops and weeds can be reliably estimated without considering aboveground biomass. Agric Ecosyst Environ 251:141-148. https://doi.org/10.1016/j.agee.2017.09.024

Hungate BA, Dukes JS, Shaw MR, Luo YQ, Field CB (2003) Nitrogen climate change. Science 302:1512-1513. https://doi.org/10.1126/science.1091390

Iizumi T et al (2017) Responses of crop yield growth to global temperature and socioeconomic changes. Sci Rep-Uk 7. https://doi.org/10.1038/s41598-017-08214-4

IPCC (2013) Climate Change 2013: The physical science basis. In: Stocker TF, Qin D, Plattner G-K, Tignor M, Allen SK, Boschung J, Nauels A, Xia Y, Bex V, Midgley PM (eds) Contribution of Working Group I to the Fifth Assessment Report of the Intergovernmental Panel on Climate Change. Cambridge University Press, Cambridge, p 1535

Ise T, Moorcroft PR (2006) The global-scale temperature and moisture dependencies of soil organic carbon decomposition: an analysis using a mechanistic decomposition model. Biogeochemistry 80:217-231. https://doi.org/10.1007 /s10533-006-9019-5

Jacobs A et al (2018) Landwirtschaftlich genutzte Böden in Deutschland - Ergebnisse der Bodenzustandserhebung. Johann Heinrich von Thünen-Institut Thünen Report:316 p. https://doi.org/10.3220/REP1542818391000

Jandl R et al (2014) Current status, uncertainty and future needs in soil organic carbon monitoring. Sci Total Environ 468:376383. https://doi.org/10.1016/j.scitotenv.2013.08.026

Johnston AE, Poulton PR, Coleman K (2009) Soil organic matter: its importance in sustainable agriculture and carbon dioxide fluxes. Adv Agron 101:1-57. https://doi.org/10.1016/S00652113(08)00801-8 
Kätterer T, Bolinder MA, Andrén O, Kirchmann H, Menichetti L (2011) Roots contribute more to refractory soil organic matter than above-ground crop residues, as revealed by a longterm field experiment. Agric Ecosyst Environ 141:184-192. https://doi.org/10.1016/j.agee.2011.02.029

Keel SG et al (2019) Loss of soil organic carbon in Swiss longterm agricultural experiments over a wide range of management practices . Agric Ecosyst Environ 286:106654. https://doi.org/10.1016/j.agee.2019.106654

Keel SG, Leifeld J, Mayer J, Taghizadeh-Toosi A, Olesen JE (2017) Large uncertainty in soil carbon modelling related to method of calculation of plant carbon input in agricultural systems. Eur J Soil Sci 68:953-963. https://doi.org/10.1111 /ejss. 12454

Kersebaum KC, Nendel C (2014) Site-specific impacts of climate change on wheat production across regions of Germany using different $\mathrm{CO} 2$ response functions. Eur J Agron 52: 22-32. https://doi.org/10.1016/j.eja.2013.04.005

Lal R (2016) Beyond COP21: Potential and challenges of the "4 per Thousand" initiative. J Soil Water Conserv 71:20a-25a. https://doi.org/10.2489/jswc.71.1.20A

Leifeld J, Fuhrer J (2010) Organic farming and soil carbon sequestration: what do we really know about the benefits? Ambio 39:585-599. https://doi.org/10.1007/s13280-0100082-8

Lugato E, Panagos P, Bampa F, Jones A, Montanarella L (2014) A new baseline of organic carbon stock in European agricultural soils using a modelling approach. Global Change Biol 20: 313-326. https://doi.org/10.1111/gcb.12292

Luo Y et al (2004) Progressive nitrogen limitation of ecosystem responses to rising atmospheric carbon dioxide. Bioscience 54:731-739 doi:Doi 10.1641/0006-3568(2004)054[0731: Pnloer]2.0.Co;2

Mayer S, Kühnel A, Burmeister J, Kögel-Knabner I, Wiesmeier M (2019) Controlling factors of organic carbon stocks in agricultural topsoils and subsoils of Bavaria. Soil Till Res 192: 22-32. https://doi.org/10.1016/j.still.2019.04.021

Melillo JM et al (2017) Long-term pattern and magnitude of soil carbon feedback to the climate system in a warming world. Science 358:101-104. https://doi.org/10.1126/science. aan2874

Minasny B et al (2017) Soil carbon 4 per mille. Geoderma 292:5986. https://doi.org/10.1016/j.geoderma.2017.01.002

Müller C, Robertson RD (2014) Projecting future crop productivity for global economic modeling. Agric Econ-Blackwell 45: 37-50. https://doi.org/10.1111/agec.12088

Parton WJ, Ojima DS, Cole CV, Schimel DS (1994) A general model for soil organic matter dynamics: sensitivity to litter chemistry, texture and management. Quantitative modeling of soil forming processes, pp 147-167. https://doi. org/10.2136/sssaspecpub39.c9

Poeplau C, Don A (2015) Carbon sequestration in agricultural soils via cultivation of cover crops - A meta-analysis. Agric Ecosyst Environ 200:33-41. https://doi.org/10.1016/j. agee.2014.10.024

Poeplau C, Don A, Vesterdal L, Leifeld J, Van Wesemael B, Schumacher J, Gensior A (2011) Temporal dynamics of soil organic carbon after land-use change in the temperate zone carbon response functions as a model approach. Global Change Biol 17:2415-2427. https://doi.org/10.1111/j.13652486.2011.02408.x
Poeplau C, Bolinder MA, Eriksson J, Lundblad M, Kätterer T (2015) Positive trends in organic carbon storage in Swedish agricultural soils due to unexpected socio-economic drivers. Biogeosciences 12:3241-3251. https://doi.org/10.5194/bg12-3241-2015

Poeplau C, Kätterer T, Bolinder MA, Borjesson G, Berti A, Lugato E (2015) Low stabilization of aboveground crop residue carbon in sandy soils of Swedish long-term experiments. Geoderma 237:246-255. https://doi.org/10.1016/j. geoderma.2014.09.010

Poeplau C, Vos C, Don A (2017) Soil organic carbon stocks are systematically overestimated by misuse of the parameters bulk density and rock fragment content. Soil 3:61-66. https://doi.org/10.5194/soil-3-61-2017

R Core Team (2018) R: A language and environment for statistical computing. R Foundation for Statistical Computing, Vienna

Reijneveld A, van Wensem J, Oenema O (2009) Soil organic carbon contents of agricultural land in the Netherlands between 1984 and 2004. Geoderma 152:231-238. https://doi. org/10.1016/j.geoderma.2009.06.007

Riggers C, Poeplau C, Don A, Bamminger C, Höper H, Dechow R (2019) Multi-model ensemble improved the prediction of trends in soil organic carbon stocks in German croplands. Geoderma 345:17-30. https://doi.org/10.1016/j. geoderma.2019.03.014

Romero-Olivares AL, Allison SD, Treseder KK (2017) Soil microbes and their response to experimental warming over time: A meta-analysis of field studies. Soil Biol Biochem 107:3240. https://doi.org/10.1016/j.soilbio.2016.12.026

Rösemann C et al (2017) Calculations of gaseous and particulate emissions from German agriculture 1990-2015: Report on methods and data (RMD) submission 2017 Thünen Report 46:424 pp. https://doi.org/10.3220/REP1490877117000

Ruosteenoja K, Raisanen J, Venalainen A, Kamarainen M (2016) Projections for the duration and degree days of the thermal growing season in Europe derived from CMIP5 model output. Int J Climatol 36:3039-3055. https://doi.org/10.1002 joc. 4535

Siddique KHM, Belford RK, Tennant D (1990) Root-shoot ratios of old and modern, tall and semidwarf wheats in a Mediterranean. Environment Plant Soil 121:89-98. https://doi.org/10.1007/Bf00013101

Sierra C, Müller M, Trumbore S (2012) Models of soil organic matter decomposition: the SoilR package, version 1.0. Geosci Model Dev 5:1045-1060. https://doi.org/10.5194 /gmd-5-1045-2012

Singh BP, Setia R, Wiesmeier M, Kunhikrishnan A (2018) Agricultural management practices and soil organic carbon storage. In: Soil carbon storage: modulators, mechanisms and modeling, pp 207-244. https://doi.org/10.1016/B978-0-12812766-7.00007-X

Sleutel S, Leinweber P, Van Ranst E, Kader MA, Jegajeevagan K (2011) Organic matter in clay density fractions from sandy cropland soils with differing land-use history. Soil Sci Soc Am J 75:521-532. https://doi.org/10.2136/sssaj2010.0094

Smith J et al (2005) Projected changes in mineral soil carbon of European croplands and grasslands, 1990-2080. Global Change Biol 11:2141-2152. https://doi.org/10.1111/j.13652486.2005.001075.x

Smith P et al (2007) Climate change cannot be entirely responsible for soil carbon loss observed in England and Wales, 1978- 
2003. Global Change Biol 13:2605-2609. https://doi. org/10.1111/j.1365-2486.2007.01458.x

Smith P (2012) Soils and climate change . Curr Opin Env Sust 4: 539-544. https://doi.org/10.1016/j.cosust.2012.06.005

Sponagel $\mathrm{H}$ et al (eds) (2005) Bodenkundliche Kartieranleitung (German manual of soil mapping, KA5). 5th edn. Bundesanstalt für Geowissenschaften und Rohstoffe, Hannover

Springob G, Kirchmann H (2002) C-rich sandy Ap horizons of specific historical land-use contain large fractions of refractory organic matter. Soil Biol Biochem 34:1571-1581. https://doi.org/10.1016/S0038-0717(02)00127-X

Sulman BN et al (2018) Multiple models and experiments underscore large uncertainty in soil carbon dynamics. Biogeochemistry 141:109-123. https://doi.org/10.1007 /s10533-018-0509-z

Taghizadeh-Toosi A, Olesen JE (2016) Modelling soil organic carbon in Danish agricultural soils suggests low potential for future carbon sequestration. Agric Syst 145:83-89. https://doi.org/10.1016/j.agsy.2016.03.004

Taghizadeh-Toosi A, Christensen BT, Hutchings NJ, Vejlin J, Kätterer T, Glendining M, Olesen JE (2014) C-TOOL: A simple model for simulating whole-profile carbon storage in temperate agricultural soils. Ecol Model 292:11-25. https://doi.org/10.1016/j.ecolmodel.2014.08.016

Taghizadeh-Toosi A, Christensen BT, Glendining M, Olesen JE (2016) Consolidating soil carbon turnover models by improved estimates of belowground carbon input. Sci Rep-Uk 6. https://doi.org/10.1038/srep32568

Tebaldi C, Knutti R (2007) The use of the multi-model ensemble in probabilistic climate projections. Philos Trans R Soc A 365:2053-2075. https://doi.org/10.1098/rsta.2007.2076

Todd-Brown K, Zheng B, Crowther TW (2018) Field-warmed soil carbon changes imply high 21 st-century modeling uncertainty. Biogeosciences 15:3659-3671. https://doi.org/10.5194 /bg-15-3659-2018

Tuomi M, Rasinmäki J, Repo A, Vanhala P, Liski J (2011) Soil carbon model Yasso07 graphical user interface. Environ Modell Softw 26:1358-1362. https://doi.org/10.1016/j. envsoft.2011.05.009

Umweltbundesamt (2016) Erarbeitung fachlicher, rechtlicher und organisatorischer Grundlagen zur Anpassung an den
Klimawandel aus Sicht des Bodenschutzes: Teil 3: Bestimmung der Veränderungen ds Humusgehalts und deren ursachen auf Ackerböden Deutschlands. UBA-Texte 26/ 2016:Dessau-Roßlau, 90 p

Van Vuuren DP et al (2011) The representative concentration pathways: an overview. Clim Chang 109:5-31. https://doi. org/10.1007/s10584-011-0148-Z

Vos C, Jaconi A, Jacobs A, Don A (2018) Hot regions of labile and stable soil organic carbon in Germany - Spatial variability driving factors. Soil 4:153-167. https://doi.org/10.5194 /soil-4-153-2018

Vos C, Don A, Hobley EU, Prietz R, Heidkamp A, Freibauer A (2019) Factors controlling the variation in organic carbon stocks in agricultural soils of Germany. Eur J Soil Sci 70: 550-564. https://doi.org/10.1111/ejss.12787

Wickham H (2009) ggplot2: elegant graphics for data analysis. Springer-Verlag, New York

Wiesmeier $\mathrm{M}$ et al (2014) Estimation of past and recent carbon input by crops into agricultural soils of southeast Germany. Eur J Agron 61:10-23. https://doi.org/10.1016/j. eja.2014.08.001

Wiesmeier M et al (2016) Projected loss of soil organic carbon in temperate agricultural soils in the 21st century: effects of climate change and carbon input trends Sci Rep-Uk 6. https://doi.org/10.1038/srep32525

Wiesmeier M, Hübner R, Kögel-Knabner I (2015) Stagnating crop yields: An overlooked risk for the carbon balance of agricultural soils? Sci Total Environ 536:1045-1051. https://doi. org/10.1016/j.scitotenv.2015.07.064

Wiesmeier M, Burmeister J, Treisch M, Brandhuber R (2017) Klimaschutz durch Humusaufbau-Umsetzungsmöglichkeiten der 4 Promille-Initiative in Bayern. In: Bayerische Landesanstalt für Landwirtschaf (ed.) Landwirtschaft im Klimawandel. Lösungen, die Geld sparen. 15. Kulturlandschaftstag, Freising-Weihenstephan, pp 21-30

Publisher's Note Springer Nature remains neutral with regard to jurisdictional claims in published maps and institutional affiliations. 